\title{
Peningkatan motivasi ekstrinsik dan kemampuan kognitif C1-C4 materi sistem ekskresi manusia melalui model pembelajaran kooperatif tipe numbered heads together (NHT) pada peserta didik kelas VIII D semester genap SMP Negeri 2 Srumbung
}

\author{
Desi Ratnasari ${ }^{{ }^{*}}$, Novi Febrianti ${ }^{2}$ \\ Pendidikan Biologi, Fakultas Keguruan dan Ilmu Pengetahuan, Universitas Ahmad Dahlan \\ Jl. Ahmad Yani (Ringroad Selatan), Tamanan, Banguntapan, Bantul. D.I. Yogyakarta 55191 \\ 1 desipkp11@gmail.com*; 2novifebrianti@pbio.uad.ac.id \\ *korespondensi penulis
}

\begin{abstract}
Abstrak
Penggunaan model pembelajaran yang kurang bervariasi mengakibatkan rendahnya motivasi ekstrinsik dan hasil belajar kognitif peserta didik pada proses pembelajaran IPA Biologi. Salah satu model pembelajaran yang dapat memotivasi peserta didik dalam belajar IPA Biologi adalah dengan menggunakan model pembelajaran kooperatif tipe Numbered Heads Together (NHT). Penelitian ini bertujuan untuk meningkatkan motivasi ekstrinsik dan hasil belajar ranah kognitif C1-C4 mata pelajaran IPA Biologi materi sistem ekskresi pada manusia dengan menggunakan model kooperatif tipe NHT terhadap peserta didik kelas VIII D SMP Negeri 2 Srumbung pada pokok bahasan mengidentifikasi organ-organ sistem ekskresi dan penyebab penyakit serta upaya pencegahannya.

Penelitian ini merupakan Penelitian Tindakan Kelas (PTK), dengan subjek penelitian adalah peserta didik kelas VIII D SMP Negeri 2 Srumbung yang berjumlah 25 peserta didik. Objek penelitian ini adalah penerapan model kooperatif tipe NHT pada materi sistem ekskresi pada manusia. Penelitian ini terdiri dari 3 siklus dengan teknik pengumpulan data yang digunakan adalah observasi, angket dan tes. Instrumen pengumpulan data berupa lembar observasi, lembar angket, dan soal post test. Teknik analisis data pada penelitian ini menggunakan analisis deskriptif kuantitatif.

Berdasarkan hasil analisis observasi terjadi peningkatan motivasi ekstrinsik peserta didik dari 59,11\% (Cukup), menjadi 65,78\% (Baik), hingga mencapai $76,89 \%$ (Baik) pada siklus III. Keterlaksanaan pembelajaran, dari $94,44 \%$ pada siklus I meningkat pada siklus II dan III menjadi $100 \%$ (Sangat Baik). Terjadi peningkatan angket motivasi ekstrinsik dari $80,40 \%$, menjadi $83,20 \%$, hingga $84,80 \%$ pada siklus III. Terjadi peningkatan hasil belajar peserta didik dari siklus I sebesar 36,00\%, menjadi $68,00 \%$, hingga $88,00 \%$ pada siklus III.
\end{abstract}

Kata kunci: motivasi ekstrinsik, kemampuan kognitif C1-C4, Numbered Heads Togethers (NHT), sistem ekskresi manusia, SMPN 2 Srumbung.

\begin{abstract}
The use of monotonous learning model causes low extrinsic motivation and cognitive learning achievement in students in the learning process of Natural Science (IPA) Biology subject. One of learning models that can be used to motivate students in learning Biology is Cooperative Learning Model Type NHT. This research aimed at improving extrinsic motivation and cognitive learning achievement of C1-C4 in IPA Biology learning for Human Excretory System materials through Cooperative Learning Model Type NHT in students of VIII D of SMP Negeri 2 Srumbung in the subject
\end{abstract}


of excretory system organ identification and disease causes, as well as disease prevention efforts.

This research was action research. The subjects of the research were students of class VIII D of SMP Negeri 2 Srumbung, with a total number of 25 students. The object of the research was the implementation of Cooperative Learning Model Type NHT for Human Excretory System materials. This study consisted of 3 cycles with observation, questionnaire and test as the data collection techniques. The data collection instruments were observation sheet, questionnaire sheet and post-test. The data analysis technique used in the research was quantitative descriptive analysis.

Based on the results of the observation analysis, there was an improvement in students extrinsic motivation from 59,11\% (Moderate) to $65,78 \%$ (Good), and even reached 76,89\% (Good) in cycle III. The learning implementation improved from $94,44 \%$ in cycle I TO $100 \%$ (Very Good) in cycle II and III. From the student motivation questionnaire, it was found that there was an improvement from $80,440 \%$ to $83,20 \%$ and reached $84,80 \%$ in cycle III. There was improvement in students learning achievement from $36,00 \%$ in cycle I to $68,00 \%$, and reached $88,00 \%$ in cycle III.

Keywords: Extrinsic motivation, C1-C4 cognitive skills, Numbered Hedas Together (NHT), human excretory system, SMPN 2 Srumbung.

\section{PENDAHULUAN}

SMP Negeri 2 Srumbung adalah salah satu sekolah yang beralamat di desa Sudimoro, Kecamatan Srumbung, Kabupaten Magelang, Provinsi Jawa Tengah. Berdasarkan nilai ulangan harian, hasil belajar peserta didik pada tahun ajaran 2017/2018 materi sistem ekskresi manusia memiliki nilai rata-rata yang paling rendah dan belum mencapai Kriteria Ketuntasan Maksimal (KKM) dibandingkan dengan materi yang lain yaitu sebesar 63,07. Hal ini menunjukkan bahwa hasil belajar IPA Biologi peserta didik khususnya materi sistem ekskresi manusia masih tergolong rendah. Guru dalam proses pembelajaran menggunakan metode ceramah, sehingga membuat peserta didik merasa bosan. Keadaan kelas menjadi tidak kondusif, peserta didik banyak yang mengobrol, ribut dan bercerita dengan teman yang lain. Peserta didik banyak tidak memperhatikan guru saat menjelaskan materi dan ketika guru memberikan kesempatan kepada peserta didik untuk bertanya, hanya beberapa peserta didik yang memberanikan diri untuk bertanya dan banyak peserta didik yang hanya diam tidak berani untuk bertanya. Guru kurang memberikan apresiasi dan tidak memberikan penghargaan kepada peserta didik yang telah menjawab pertanyaan, sehingga peserta didik menjadi kurang semangat dalam belajar. Hal ini menunjukkan masih rendahnya motivasi ekstrinsik terhadap peserta didik dalam proses pembelajaran. Menurut Suryabrata dalam Kompri (2015:6) motivasi ekstrinsik dapat timbul karena ada rangsangan dari luar individu 
dapat berupa pemberian penghargaan, pujian, dan tepuk tangan. Hal-hal tersebut dapat mendorong peserta didik untuk lebih giat dalam belajar.

Melihat permasalahan tersebut, maka perlu diterapkan suatu pembelajaran kooperatif yang dapat meningkatkan motivasi ekstrinsik dan hasil belajar. Salah satu model pembelajaran kooperatif yang dapat diterapkan adalah model pembelajaran Numbered Heads Together (NHT). NHT dapat memberikan kesempatan kepada peserta didik untuk saling membagikan ide-ide, mempertimbangkan jawaban yang paling tepat serta mendorong peserta didik untuk meningkatkan semangat berdiskusi. Menurut Salam, Reskiawati (2017: 174) model pembelajaran kooperatif merupakan salah satu model pembelajaran yang menutut siswa agar dapat berperan secara aktif pada sebuah kelompok dalam proses pembelajaran. Hal ini didukung oleh hasil penelitian Ekawati (2005: 78) yang menyatakan bahwa model pembelajaran kooperatif tipe NHT lebih efektif dari pada pembelajaran konvensional.

Menurut Susilo \& Khabibah (2013:1-8) model pembelajaran kooperatif tipe NHT adalah model pembelajaran yang dilakukan secara berkelompok beranggotakan $4-5$ orang peserta didik dan guru memberi nomor kepada setiap peserta didik dalam kelompok. Kelompok yang dibentuk mempunyai tingkat kemampuan bervariasi. Setiap anggota kelompok diberi tanggung jawab untuk memecahkan masalah atau soal yang telah diberi sesuai dengan nomor-nomor yang telah ada. Anggota kelompok saling menjelaskan kepada sesama teman anggota kelompoknya, sehingga semua anggota kelompok mengetahui jawaban dari semua soal yang diberikan. Selanjutnya, guru menyebut satu nomor para peserta didik dari tiap kelompok dan yang telah disebut nomornya harus menyiapkan jawabannya untuk seluruh kelas dan mempresentasikan di depan kelas.

Model kooperatif tipe NHT ini tepat diterapkan untuk mengatasi permasalahan pembelajaran yang telah diuraikan, karena dengan pembelajaran kooperatif tipe NHT ini akan membuat peserta didik tidak jenuh dalam kegiatan pembelajaran dapat sharing dengan teman-temannya untuk memecahkan permasalahan yang diberikan oleh guru, karena guru hanya sebagai fasilitator untuk mengembangkan pengetahuan peserta didik ( Mulyana, 2016:334)

Menurut Nursyamsi, dkk (2016: 1997) kelebihan model NHT yaitu: (1) Melatih rasa tanggung jawab untuk berusaha menjawab dan memahami permasalahan yang diberikan oleh guru. (2) Membuat peserta didik menjadi siap. (3) Kegiatan belajar dalam kelompok peserta didik yang lebih mampu dapat membantu dan dapat memotivasi peserta didik yang kurang sehingga pembelajaran lebih menyenangkan. (4) Dapat meningkatkan prestasi belajar peserta 
didik. (5) Interaksi antara guru dengan peserta didik terjalin dengan baik sehingga peserta didik tidak merasa canggung dalam mengajukan pendapat ataupun pertanyaan.

Berdasarkan latar belakang di atas, maka tujuan penelitian ini adalah mengetahui keterlaksanaan proses pembelajaran IPA Biologi pada materi sistem ekskresi manusia dapat terlaksana sesuai langkah-langkah model pembelajaran Numbered Heads Together (NHT) dikelas VIII D semester 2 SMP Negeri 2 Srumbung, mengetahui besarnya peningkatan motivasi ekstrinsik dan hasil belajar kognitif C1-C4 peserta didik dengan menggunakan model pembelajaran NHT pada materi sistem ekskresi manusia di kelas VIII D SMP N 2 Srumbung

\section{METODE}

Penelitian ini merupakan Penelitian Tindakan Kelas (PTK) yang dilakukan dalam tiga siklus tindakan. Teknik pengumpulan data menggunakan tes dan observasi. Instrumen pengumpulan data menggunakan soal post test, angket dan lembar observasi. Penelitian tindakan kelas meliputi empat tahap yaitu: (1) perencanaan, (2) pelaksanaan, (3) pengamatan dan (4) refleksi. Analisis yang digunakan adalah analisis data deskriptif kuantitatif. Adapun data yang akan dianalisis yaitu lembar observasi dan soal post test.

1. Analisis hasil observasi keterlaksanaan pembelajaran dan motivasi ekstrinsik peserta didik

Data yang dianalisis yaitu hasil observasi keterlaksanaan pembelajaran dan kerja sama siswa dengan menggunakan rumus sebagai berikut :

$$
\mathrm{NP}=\frac{R}{S M} \mathrm{X} 100 \%
$$

Keterangan :

NP : Nilai Akhir

R : Jumlah keseluruhan skor yang diperoleh

SM : jumlah keseluruhan skor maksimal

$100 \quad$ : Bilangan tetap

(Purwanto, 2013:102) 
Tabel 1. Kriteria Tingkat Keberhasilan

\begin{tabular}{cc}
\hline Nilai & Keterangan \\
\hline $\mathbf{8 0 - 1 0 0} \%$ & Sangat Baik \\
$\mathbf{6 6}-\mathbf{7 9} \%$ & Baik \\
$\mathbf{5 6}-\mathbf{6 5} \%$ & Cukup \\
$\mathbf{2 0}-\mathbf{5 5} \%$ & Kurang \\
$<\mathbf{2 0} \%$ & Kurang Sekali \\
\hline
\end{tabular}

(Modifikasi dari Arikunto, 2009:35)

2. Analisis hasil tes

a. Menghitung nilai rata-rata hasil belajar peserta didik:

$$
x=\frac{\sum \mathrm{x}}{N}
$$

Keterangan :

$\mathrm{X}$ : Nilai rata-rata

$\sum \mathrm{x}$ : Jumlah nilai semua peserta didik

$\mathrm{N}$ : Banyak peserta didik yang mengikuti tes

(Sudjana, 2013: 109).

b. Persentase keberhasilan hasil belajar peserta didik

Persentase keberhasilan hasil belajar siswa dihitung dengan rumus:

$$
P=\frac{\text { Jumlah siswa yang tuntas }}{\text { Jumlah keseluruhan siswa }} X 100
$$

Tabel 2. Kriteria Pencapaian Hasil Belajar

\begin{tabular}{cc}
\hline Persentase & Kriteria \\
\hline$>80 \%$ & Sangat Tinggi \\
$61-80 \%$ & Tinggi \\
$41-60 \%$ & Sedang \\
$21-40 \%$ & Rendah \\
$<21 \%$ & Sangat rendah
\end{tabular}

(Arikunto, 2006: 210)

Indikator keberhasilan dari penelitian ini yaitu: (1) Terlaksananya proses pembelajaran dengan model pembelajaran NHT. (2) Penelitian dikatakan berhasil apabila motivasi ekstrinsik peserta didik telah mencapai kriteria baik yaitu $\geq 66$. (3) Penelitian dikatakan berhasil apabila $\geq 75 \%$ dari peserta didik kelas VIII D SMP Negeri 2 Srumbung Magelang mendapatkan nilai minimal 75 pada mata pelajaran sistem ekskresi manusia, sesuai dengan KKM yang telah ditetapkan di SMP Negeri 2 Srumbung Magelang yaitu 75. 


\section{HASIL DAN PEMBAHASAN}

Berikut ini merupakan data hasil penelitian peningkatan motivasi ekstrinsik dan kemampuan kognitif C1-C4 materi sistem ekskresi manusia melalui model pembelajaran kooperatif tipe Numbered Heads Together (NHT) pada peserta didik kelas VIII D semester genap SMP Negeri 2 Srumbung

\section{Keterlaksanaan Pembelajaran}

Keterlaksanaan pembelajaran yang meliputi kegiatan guru. Berikut ini merupakan hasil observasi keterlaksanaan pembelajaran di kelas VIII D SMP negeri 2 Srumbung Magelang.

Tabel 3. Hasil Keterlaksanaan Pembelajaran

\begin{tabular}{cccc}
\hline No & $\begin{array}{c}\text { Siklus } \\
\text { Pembelajaran }\end{array}$ & Persentase (\%) & Kriteria \\
\hline Siklus I & $95,83 \%$ & Sangat Tinggi \\
Siklus II & $100 \%$ & Sangat Tinggi \\
Siklus III & $100 \%$ & Sangat Tinggi \\
\hline
\end{tabular}

Berdasarkan analisis data observasi keterlaksanaan proses pembelajaran menggunakan model pembelajaran NHT pada siklus I diperoleh persentase sebesar 95,83\% dalam kriteria sangat tinggi. Berdasarkan analisis data observasi keterlaksanaan proses pembelajaran ada langkah-langkah yang belum terlaksana optimal yaitu guru belum guru menyampaikan kepada peserta didik untuk menjawab semua soal sehingga saat presentasi peserta didik sebagian besar belum menjawab semua soal yang telah didiskusikan.

Keterlaksanaan pembelajaran pada siklus II pada materi bagian organ paru-paru dan hati adalah sebesar $100 \%$ (sangat tinggi). Peserta didik yang mengikuti proses pembelajaran pada siklus II sebanyak 25 peserta didik. Bedasarkan analisis data observasi keterlaksanaan proses pembelajaran pada siklus II guru telah melaksanakan pembelajaran sesuai dengan prosedur pembelajaran. Hal ini dikarenakan guru sudah menyampaikan kepada peserta didik untuk menjawab semua soal sehingga saat presentasi peserta didik.

Pembelajaran pada siklus III yaitu materi gangguan penyakit dan upaya pencegahan pada sistem ekskresi manusia. Peserta didik yang mengikuti proses pembelajaran pada siklus III sebanyak 25 peserta didik. Berdasarkan analisis data observasi keterlaksanaan proses pembelajaran dengan menggunakan model pembelajaran NHT pada siklus III guru telah melaksanakan pembelajaran sesuai dengan prosedur pembelajaran

Berdasarkan analisis data observasi diperoleh persentase keterlaksanaan proses pembelajaran pada siklus II dan III sebesar $100 \%$ dalam kriteria sangat tinggi. Hal ini dikarenakan guru sudah menguasai kelas dengan baik selama proses pembelajaran, peserta 
didik lebih akrab dengan guru sehingga peserta didik tidak merasa canggung. Pembelajaran yang tidak membosankan membuat peserta didik lebih semangat dalam proses pembelajaran.

\section{Motivasi ekstrinsik peserta didik}

Pada proses embelajaran diperlukan keterlibatan peserta didik secara optimal agar proses pembelajaran lebih bermakna. Untuk mewujudkan keberhasilan proses pembelajaran IPA Biologi diperlukan adanya motivasi peserta didik. Peran guru sebagai fasilitator dan motivator sangat penting untuk meningkatkan motivasi belajar peserta didik (Arnentis, 2009: $1)$.

Berikut ini merupakan data hasil observasi motivasi ekstrinsik peserta didik di kelas VIII D SMP negeri 2 Srumbung Magelang.

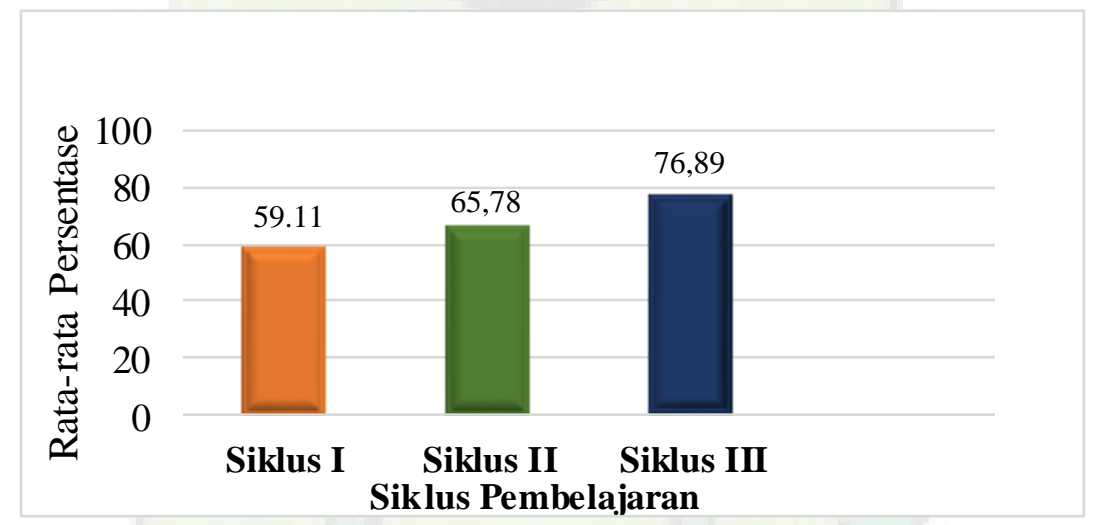

Gambar 1. Diagram perbandingan observasi motivasi ekstrinsik peserta didik pada kelas VIII D pada tiap siklus

Berdasarkan hasil observasi motivasi ekstrinsik peserta didik secara umum dari siklus I sampai siklus III diketahui terjadi peningkatan motivasi ekstrinsik siklus I diperoleh hasil 59,11\%, siklus II 65,78\%, dan siklus III 76,89\%. Penggunaan model pembelajaran NHT dapat meningkatkan motivasi ekstinsik belajar peserta didik. Hal tersebut salah satunya ditunjukkan dengan peserta didik saat bersemangat untuk maju ke depan kelas mengeluarkan pendapat saat berdiskusi dan saling membantu temannya yang mengalami kesulitan dalam belajar. Hal ini sesuai dengan pendapat Hamdu (2011: 91) bahwa peserta didik yang bermotivasi tinggi dalam belajar memungkinkan akan memperoleh hasil belajar yang tinggi pula, artinya semakin tinggi motivasinya, semakin tinggi intensitas usaha dan upaya yang dilakukan, maka semakin tinggi prestasi belajar yang diperolehnya.

Motivasi ekstrinsik peserta didik juga dinilai dengan menggunakan alat bantu penialaian yang berupa lembar angket motivasi ekstrinsik. Perbandingan rata-rata hasil siklus I sampai siklus III dapat dilihat pada Gambar 2. 
Gambar 2. Diagram perbandingan rata-rata angket peserta didik kelas VIII D pada tiap siklus.

Berdasarkan data diatas hasil angket peserta didik pada siklus I diperoleh 80,40\% yang

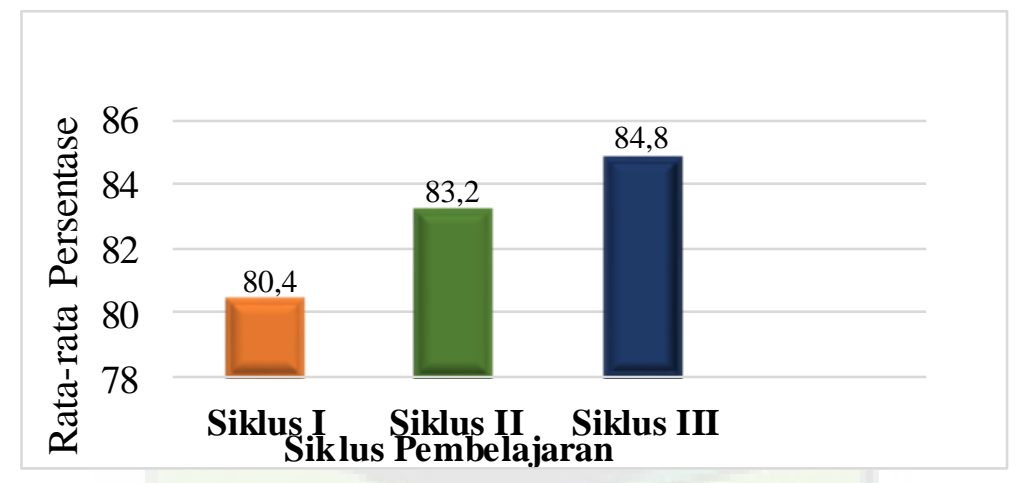

didapatkan dari 77,33\% peserta didik menyukai adanya penghargaan dalam belajar, $80,00 \%$ adanya kegiatan menarik dalam belajar dan 84,00\% adanya lingkungan belajar yang kondusif. Siklus II diperoleh rata-rata 83,20\% yang didapatkan dari 70,67\% peserta didik menyukai adanya penghargaan dalam belajar. Hal ini karenakan peserta didik merasa senang apabila diberi pujian dari guru. Hal ini sesuai dengan pendapat Suprihatin (2015:76) menyatakan bahwa pujian adalah bentuk reinforcement yang positif dan memberikan motivasi yang baik bagi peserta didik. Pemberian pujian kepada peserta didik akan memupuk suasana yang menyenangkan dan mempertinggi motivasi belajar sekaligus akan membangkitkan harga diri. Adanya kegiatan menarik dalam belajar 85,00\%, dan 93,33\% menunjukkan adanya lingkungan belajar yang kondusif. Serta siklus III rata- rata yang diperoleh mencapai $84,80 \%$ yang didapatkan dari $72,00 \%$ peserta didik menyukai adanya penghargaan dalam belajar $87,00 \%$, serta menunjukkan adanya kegiatan menarik dalam belajar 94,67\% menunjukkan adanya lingkungan belajar yang kondusif. Hal ini dikarenakan peserta didik sudah berusaha menegur temannya yang ribut dikelas demi kelancaran dalam menyimak pembelajaran yang disampaikan oleh guru.

\section{Hasil Belajar Peserta Didik}

Berikut ini merupakan data hasil belajar peserta didik pada materi sistem ekskresi manusia di kelas VIII D SMP negeri 2 Srumbung Magelang. 


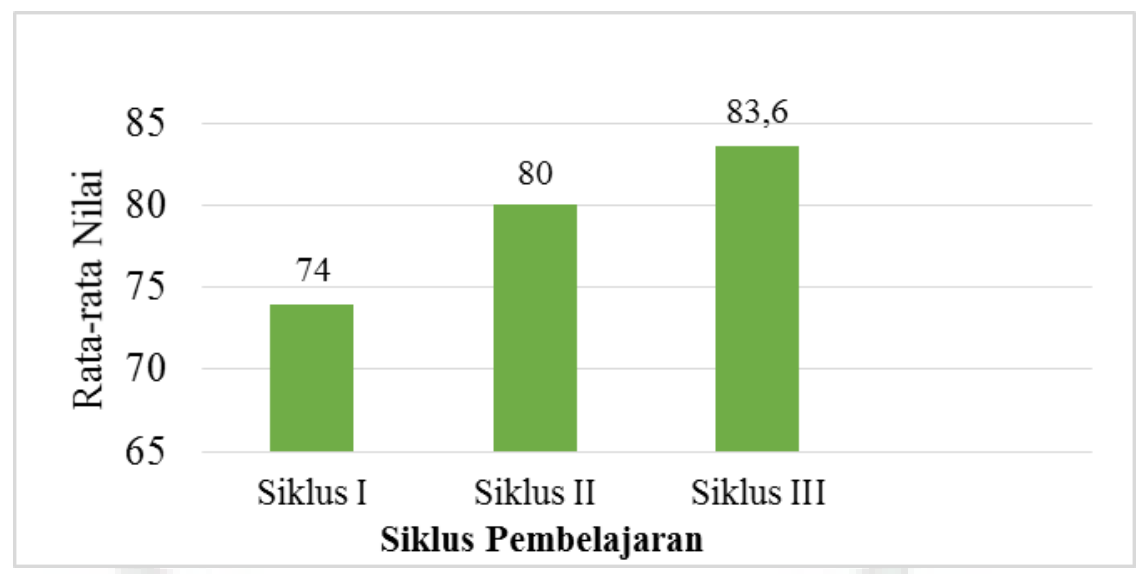

Gambar 3. Diagram perbandingan nilai rata-rata hasil belajar peserta didik kelas VIII D pada tiap siklus

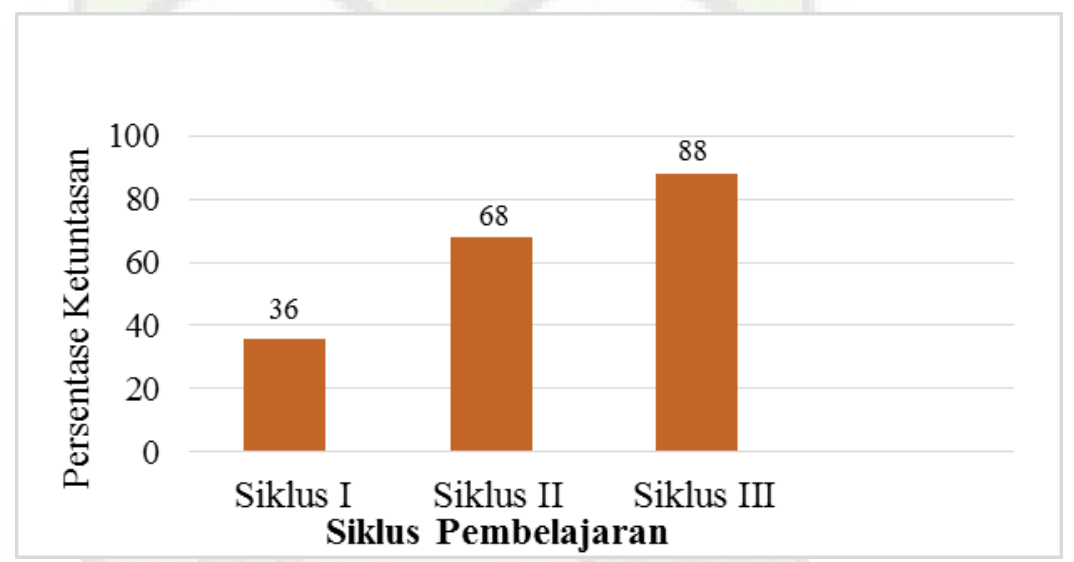

Gambar 4. Diagram Perbandingan Persentase Ketuntasan Klasikal pada Setiap Siklus

Berdasarkan analisis data hasil belajar pada materi sistem ekskresi manusia melalui model pembelajaran NHT siklus I dapat dilihat pada Gambar 3, bahwa memperoleh nilai rata-rata 74 dalam kriteria tinggi. Akan tetapi hasil belajar pada siklus I tersebut belum mencapai KKM yang ditetapkan oleh sekolah yaitu 75. Peserta didik yang tuntas mendapatkan nilai $>75$ sebanyak 9 peserta didik dengan persentase $36 \%$. Berdasarkan persentase ketuntasan klasikal peserta didik yang tuntas belum mencapai indikator keberhasilan yang telah ditetapkan yaitu $75 \%$. Hal tersebut diakibatkan peserta didik belum terbiasa dengan pembelajaran yang dilakukan. Ini terlihat dari masih adanya peserta didik yang bertanya tentang tata cara pembelajaran dengan menggunakan model NHT. Guru menjelaskan langkah-langkah dengan menggunakan model pembelajaran NHT, banyak 
peserta didik yang tidak memperhatikan pembelajaran yang dilakukan. Sedangkan dengan model pembelajaran NHT peserta didik bertanggung jawab sendiri untuk mencari tahu konsep dari mengumpulkan informasi dan fakta-fakta yang ditemui dalam pengamatan dan penyidikan.

Kebanyakan dari peserta didik masih bingung dengan apa yang akan mereka lakukan, mereka cenderung banyak bertanya kepada guru. Selain itu perhatian, keaktifan dalam melakukan tanya jawab, menerima, menanggapi, dan menghargai pendapat peserta didik masih kurang. Menurut Susilo (2009:73) menyatakan bahwa untuk menjamin hasil belajar yang baik, maka peserta didik harus mempunyai perhatian terhadap bahan yang dipelajarinya, jika bahan pelajaran tidak menjadi perhatian peserta didik, maka dapat menimbulkan kebosanan, sehingga ia tidak suka lagi belajar. Agar peserta didik dapat belajar dengan baik, usahakanlah bahan pelajaran selalu menarik perhatian dengan cara mengusahakan pelajaran itu sesuai dengan hobi atau bakatnya. Hal ini terlihat sikap peserta didik yang malu dan belum berani mengemukakkan pendapat dengan baik dengan teman satu kelompok maupun dalam diskusi kelas. Bahwa kualitas pembelajaran yang dilaksanakan dapat dilihat dari hasil belajar yang dicapai oleh peserta didik.

Berdasarkan analisis data pada Gambar 3, diketahui nilai rata-rata peserta didik sebesar 80.00 dalam kriteria tinggi. Hasil belajar peserta didik pada siklus II tersebut sudah mencapai KKM yang ditetapkan oleh sekolah yaitu 75. Berdasarkan analisis data pada Gambar 3, peserta didik yang tuntas mendapatkan nilai $>75$ sebanyak 17 peserta didik dengan persentase sebesar $68 \%$ dalam kriteria baik. Berdasarkan persentase tersebut jumlah peserta didik yang tuntas belum mencapai indikator keberhasilan yang telah ditetapkan yaitu $75 \%$. Hal ini dikarenakan peserta didik masih kurang memperhatikan pada saat guru menjelaskan sehingga pemahaman peserta didik terhadap materi masih kurang. Hal tersebut sesuai dengan pernyataan yang diungkapkan oleh Dimyati dan Moedjiono (2009: 254) bahwa peserta didik yang belum terbiasa dengan penggunaan metode, strategi atau model tertentu dapat berpengaruh terhadap proses belajar yang akan mempengaruhi hasil belajar peserta didik. Namun, untuk memastikan dan melihat hasil belajar kognitif peserta didik meningkat atau tidak sekaligus menyelesaikan materi sistem ekskresi manusia, maka penelitian dilanjutkan pada siklus III.

Berdasarkan analisis data pada Gambar 3, nilai rata-rata peserta didik sebesar 83,60 dalam kriteria sangat tinggi. Hasil belajar pada siklus III sudah melampaui KKM yang ditetapkan oleh sekolah yaitu 75. Peserta didik yang tuntas mendapatkan nilai $>75$ sebanyak 
22 peserta didik dengan persentase sebesar 88\% dalam kriteria sangat tinggi. Berdasarkan persentase ketuntasan klasikal sudah mencapai indikator keberhasilan yang telah ditetapkan yaitu $75 \%$. Hal ini dikarenakan peserta didik lebih tertarik belajar dengan cara berdiskusi karena lebih menyenangkan, melalui diskusi peserta didik dapat saling membantu dalam menguasai materi, sehingga meningkatkan pemahaman peserta didik. Hal tersebut sejalan dengan pendapat yang dikemukakan oleh Isjoni (2013: 74) bahwa model pembelajaran kooperatif tipe NHT menekankan adanya aktivitas dan interaksi diantara peserta didik untuk saling memotivasi dan saling membantu dalam menguasai materi pelajaran untuk mencapai hasil belajar yang maksimal.

Ketuntasan peserta didik dari siklus I ke siklus II mengalami peningkatan sebesar $32 \%$ dan nilai rata-rata peserta didik meningkat sebesar $6 \%$. Hal ini dikarenakan pada siklus I peserta didik kurang memperhatikan pada saat guru menjelaskan materi, peserta didik belum paham dengan teknis pembelajaran menggunakan model NHT dan kurangnya antusias peserta didik dalam belajar, sehingga ketuntasan dan nilai rata-rata peserta didik dari siklus I ke siklus II mengalami peningkatan. Sedangkan dari siklus II ke siklus III ketuntasan klasikal meningkat sebesar $20 \%$ dan nilai rata-rata peserta didik meningkat sebesar 3,6\%. Hal ini karena peserta didik lebih antusias dalam belajar, sehingga memperhatikan pada saat guru menjelaskan materi dan peserta didik dapat bekerja sama dengan optimal, sehingga pemahaman peserta didik terhadap materi semakin meningkat. Hal tersebut menyebabkan ketuntasan dan nilai rata-rata peserta didik dari siklus II ke siklus III mengalami peningkatan lebih tinggi. Pernyataan diatas sesuai dengan pendapat Kurniawan, dkk (2017: 108-117) menyatakan bahwa antusiasme belajar merupakan gairah, gelora semangat, minat besar terhadap kegiatan belajar. Semakin tinggi antusiasme belajar peserta didik, maka untuk mencapai prestasi yang tinggi juga akan semakin besar, begitupun sebaliknya.

Pelaksanaan siklus II dan siklus III dilakukan refleksi ternyata diperoleh peningkatan hasil belajar IPA Biologi peserta didik cukup besar dengan melihat nilai rerata post-test pada peserta didik kelas VIII D SMPN 2 Srumbung adalah 80,00. Hasil yang diperoleh dapat dilihat setelah menggunakan model pembelajaran NHT, peserta didik yang mengalami ketuntasan belajar ada 17 peserta didik dan 8 peserta didik yang tidak tuntas. Peningkatan hasil belajar juga terlihat pada siklus III diperoleh nilai rerata post test mencapai 83,60. Peserta didik yang mengalami ketuntasan sebanyak 22 peserta didik dan 3 peserta didik yang tidak tuntas. Ketuntasan ini sesuai dengan prinsip belajar menurut Djamarah (2009: 215) yaitu nilai ketuntasan persentase pada ranah kognitif $\mathrm{C} 1-\mathrm{C} 4$ peserta didik yaitu $75 \%$ peserta didik yang telah tuntas belajar menggunakan model NHT sebanyak 22 peserta didik. 
Sehingga pada siklus III dapat dikatakan tuntas klasikal tercapai. kenaikan terjadi karena adanya beberapa upaya perbaikan dari refleksi. Tujuan dari refleksi adalah untuk mengingaktkan kembali peserta didik dengan peljaran yang sudah mereka pelajari pada saat pembelajaran. Sandars (2009: 685-695) menjelaskan bahwa refleksi dalam konteks pendidikan dimaknai sebagai proses atau tindakan untuk melihat kembali ke masa lampau dengan tujuan untuk memproses pengalamn yang didapat sehingga diinterprestasi atau dianalisis. Perbaikan yang dilakukan yaitu, penggunaan model pembelajaran NHT secara optimal. Hal ini dimaksudkan untuk membuat peserta didik terbiasa dengan model pembelajaran yang lebih menekankan pada kerjasama dan tukar pendapat antar peserta didik dan mencari informasi dari berbagai sumber, sehingga peserta didik lebih paham terhadap materi yang disampaikan.

\section{SIMPULAN}

Berdasarkan hasil penelitian dan pembahasan, maka dapat ditarik kesimpulan adalah sebagai berikut: (1) Penerapan model pemebelajaran kooperatif tipe Numbered Heads Together (NHT) terlaksana sesuai dengan sintak pembelajaran. (2) Peningkatan Motivasi belajar pada peserta didik ditandai dengan meningkatnya rata persentase hasil observasi dari siklus I sampai dengan Siklus III dari 59,11\%, 65,78\% hingga menjadi 76,89\%. (3) Peningkatan hasil belajar peserta didik diperoleh dari rata rata kemampuan kognitif dari Siklus I sampai dengan Siklus III yakni 74,00\%, 80,00\%, hingga 83,60\%.

\section{REFERENSI}

Arikunto, Suharsimi. 2006. Prosedur Penelitian Suatu Pendekatan Praktek. Jakarta: PT. Rineka Cipta.

2009. Evaluasi Program Pendidikan. Jakarta: PT Bumi Aksara.

Arnentis. 2010. Upaya peningkatan motivasi dan aktivitas belajar biologi siswa melalui strategi Think Talk Write siswa kelas XI SMA Negeri Kampar Kiri tahun ajaran 2009/2010. Artikel. Pekanbaru: Program Studi Pendidikan Biologi Jurusan PMIPA FKIP Universitas Riau. (Diakses Tanggal 20 Agustus 2019 pada jam 20.00 WIB).

Dimyati dan Mudjiono. 2009. Belajar dan Pembelajaran. Jakarta: Rineka Cipta.

Djamarah, Syaiful Bahri. 2009. Guru dan Anak Didik dalam Interaksi Edukatif. Jakarta: PT Rineka Cipta.

Ekawati, Desti Nurlela. 2005. Keefektifan Model Pembelajaran Kooperatif Tipe Numbered Heads Together (NHT) untuk Meningkatkan Pokok Bahasan Persamaan Linear Dua Peubah pada Siswa Kelas II Semester 2 SLTP Negeri 9 Purwokwrto Tahun Pelajaran 2003/2004. (Skripsi). Semarang: Jurusan Matematika FMIPA Universitas Negeri Semarang. 
Hamdu, Ghullam. 2011. Pengaruh Motivasi Belajar Siswa Terhadap Prestasi Belajar IPA Di Sekolah Dasar. Jurnal Penelitian Pendidikan, 12(1): 91.

Isjoni. 2013. Pembelajaran Kooperatif. Yogyakarta: Pustaka Pelajar.

Kompri. 2015. Motivasi Pembelajarn Perspektif Guru dan Siswa. Bandunng: PT Remaja Rosdakarya Offset.

Kurniawan, A.S.dkk. 2017. Antusiasme Belajar Siswa Kelas X Ilmu Pengetahuan Bahasa Pada Lintas Minat Biologi Di MAN 2 Model Medan. Jurnal Pelita Pendidikan. 5(1): 108:117.

Mulyana. 2016. Penerapan Model kooperatif Model Pembelajaran Kooperatif Tipe Numbered Heads Together (NHT) Untuk Meningkatkan Hasil Belajar Siswa Pada Materi Kenampakan Alam Dan Sosial Budaya. Jurnal Pena Ilmiah, 1(1): 334.

Nursyamsi, S.Y. dkk. 2016. Pengaruh Strategi Pembelajaran Numbered Heads Together (NHT) Terhadap Hasil Belajar Siswa SMA Negeri 1 Muara Badak. Jurnal pendidikan. 1(10): 1997.

Purwanto, Ngalim. 2013. Prinsip-prinsip Dan Teknik Evaluasi Pengajaran. Bandung: PT Remaja Rosdakarya.

Sandars, John. 2009. The Use Reflection in Medical Education: AMEE Guide No 44. Med Teach, 31(8): 685-695.

Susilo, Muhammad Joko. 2009. Sukses dengan Gaya Belajar. Yogyakarta: Pinus.

Sudjana, 2013. Penelitian Hasil Proses Belajar Mengajar. Bandung: Rosdakarya.

Susilo, Yudi \& Siti Khabibah. 2013. Peningkatan Motivasi Belajar Sswa Melalui Model Pembelajaran Kooperatif Tipe Numbered Heads Together (NHT) Materi Ajar Perbandingan dan Fungsi Trigonometri Pada Siswa kelas X. Jurnal Mahasiswa Teknologi Pendidikan, 2(2): 1-8.

Suprihatin, Siti. 2015. Upaya Guru Dalam Meningkatkan Motivasi Belajar Siswa. Jurnal Pendidikan Ekonomi. 3(1): 76.

Salam, Reskiwati. 2017. Efektivitas Penggunaan Model Pembelajaran Kooperatif Tipe Think Pair Share (TPS) Untuk Meningatkan Kepercayaan Diri dan Komunikasi. Jurnal: Matematis. Jurnal Penelitian Semester Gasal SMAN 2 Karanganyar Tahun Ajaran 2012/2013. Jurnal: Pendidikan Kimia (JPK): 2(4): 174-181. 